\title{
Stratigraphic architecture and depositional environment of the Paleocene-Lower Eocene aquifers system (Douala onshore basin, SW Cameroon)
}

\author{
Serge Parfait Koah Na Lebogo ${ }^{1}$. Dieudonnée Bisso ${ }^{1}$. Jeannette Ngo Elogan Ntem ${ }^{2} \cdot J^{\prime}$ seph Mvondo Ondoa ${ }^{1}$
}

Received: 7 February 2020 / Accepted: 24 November 2020 / Published online: 4 January 2021

(c) The Author(s) 2021

\begin{abstract}
The Paleocene-Lower Eocene N'kapa Formation has long been considered as an important groundwater and hydrocarbon resource in the eastern edge of the Douala Basin. The present study's aim is to establish a possible link between the geological nature of this formation and the quality of potential aquifers using Gamma Ray well log, cuttings and outcrops through sedimentology and sequence stratigraphy studies. The results obtained from this study show that: lithofacies are dominated by clays, silts and sands/sandstones; gamma ray electrofacies are funnel-shaped to cylindrical-shaped with some bell-shaped; depositional environments are continental to shallow marine dominated by fluvial and sometimes tidal processes; fluvial channel-fill, tidal channel-fill and delta front bars sands are potential aquifers; sequence stratigraphy analysis reveals two transgressive-regressive cycles of second order (Danian to Selandian and Thanetian to Ypresian), two Highstand System Tracts, one Transgressive System Tract and one Lowstand System Tract; the high-resolution geometry of these sandy/ sandstone sedimentary bodies shows that their distribution is linked to the hydrodynamic factors and the topography of the depositional environment. A total of two types of lithological facies of the reservoir levels were defined according to the volume of clay: clean sandstone (0-15\%) and low clayey sandstone (15-30\%). The gamma ray well log correlation shows that the thickness of the reservoir levels is variable and that the clay content $\left(\mathrm{V}_{\mathrm{sh}} \%\right)$ increases from the NE to the SW. As a result, the best potential aquifers appear to correspond to the fluvial channel-fill sands deposited during the base-level fall of Upper Paleocene age (Lower Thanetian).
\end{abstract}

Keywords Douala onshore basin $\cdot$ Paleocene-Lower Eocene $\cdot$ Aquifer system $\cdot$ Depositional environments $\cdot$ Stratigraphic architecture

Serge Parfait Koah Na Lebogo

sergekoah@yahoo.com

Dieudonnée Bisso

dbisso2002@yahoo.com

Jeannette Ngo Elogan Ntem

ngoeloganntem@yahoo.fr

Joseph Mvondo Ondoa

jomvondo_2005@yahoo.com

1 Department of Earth Sciences, University of Yaoundé I, P.O. Box 812, Yaounde, Cameroon

2 Higher Teachers' Training College, University of Yaounde I, P.O. Box 47, Yaounde, Cameroon

\section{Introduction}

The Douala basin is located along the Gulf of Guinea (Fig. 1) and belongs to the rift system of the Equatorial Atlantic Margin. The Paleocene-Lower Eocene N'kapa Formation, with an average thickness of $200-400 \mathrm{~m}$ in the onshore part (Pauken et al. 1991; Coward et al. 1999), has long been considered as a target for groundwater and petroleum prospection. Several hydrogeological survey of this formation was carried out in the eastern Douala onshore basin by companies. The first results of these survey showed that this formation was the best aquifer system in the Douala basin in terms of its lithology and thickness. Two different lithostratigraphic units have been identified: a sandy mudstone unit whose thickness increases from East to West ( $80 \mathrm{~m}$ in the Pibissou well, $110 \mathrm{~m}$ in the Razel 2 well) and a unit composed on average of 200-250 $\mathrm{m}$ of fine to

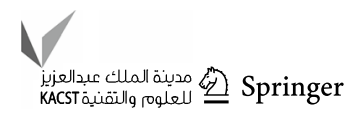




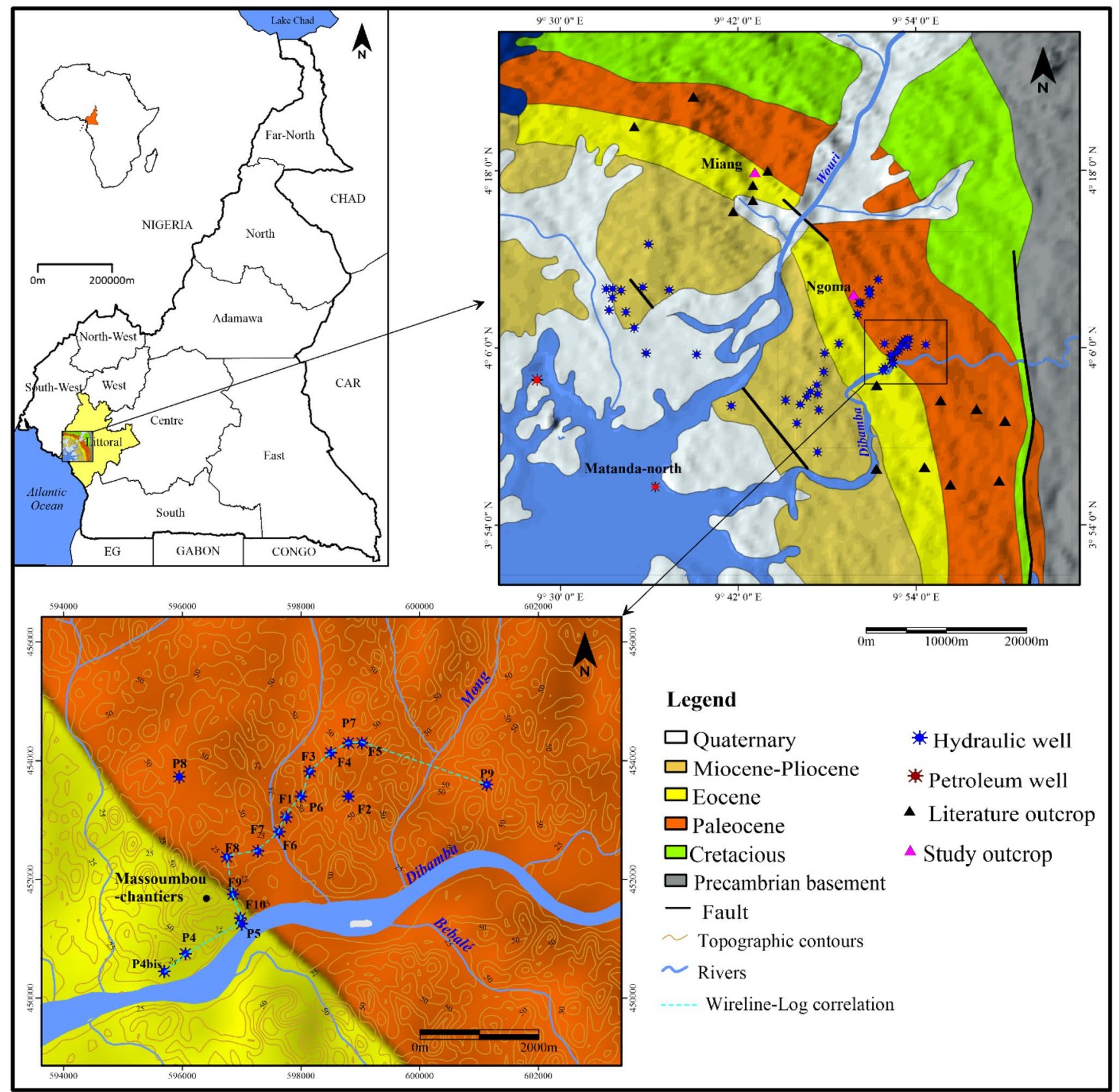

Fig. 1 Location and simplified geological map of the study area. Location of well logs, reference petroleum wells, outcrops and well logs cross section are shown on the map

coarse-grained sandstones $(0.1-0.3 \mathrm{~mm})$ interstratified with thin mudstone strata (Manga 2008). In the western part of the basin, the continental sediments give way to a marine sedimentation that is essentially made of mudstones. But the exploitation works of this aquifer system show irregularities due to its heterogeneous lithology and water quality. The results of physico-chemical analyses show the presence of pyrite on some of the aquifer units, and high iron content can also be noted. In the present study, the gamma ray $\log$ data were used together with outcrop informations to establish sedimentological characteristics of sedimentary bodies aquifers and to understand the spatio-temporal distribution. The Gamma ray response depends on the measure of the rock radioactivity which reflects the clay-mineral content and hence the grain size and depositional energy (Serra 1986; Rider 1991). The increase in the measured radioactivity reflects the increase in clay content and hence the decrease in the depositional energy. In the silico-clastic series studied, Emery and Myers (1996) have shown that the most direct method for the identification of electrofacies in 
terms of depositional environments from total gamma ray responses is based on amplitude variations of the gamma ray motif. Also, several authors (Bourquin et al. 1993; Hamon and Merzeraud 2005; Mohammad 2015) have shown that the Gamma-ray log data can be used in sequence stratigraphy framework. This method will make it possible to determine the depositional model and the stratigraphic architecture of Paleocene-Lower Eocene aquifer system.

\section{Geological setting}

The Douala onshore basin is about $25 \mathrm{~km}$ wide and covers a total area of $6955 \mathrm{~km}^{2}$. The sedimentary deposits of Cretaceous to Quaternary age overly Precambrian basement (Fig. 2). Three major tectonic and sedimentary episodes can be distinguished: a rift phase in the Early Cretaceous; a drift phase during the Late Cretaceous and a short compressive episode in the Tertiary (Pauken et al. 1991; Meyers et al. 1996; Lawrence et al. 2002). The depositional sequences associated with these phases include seven formations (Nguene et al. 1992; Brownfield and Charpentier 2006). The syn-rift sequence affects both the Precambrian basement and the Lower Mundeck Formation of BerriasianBarremian age; while the post-rift sequence is characterized by the Upper Mundeck Formation (Aptian-Cenomanian), Logbadjeck Formation (Cenomanian-Camapanian), Logbaba Formation (Maestrichtian), N'kapa Formation (Paleocene-Lower Eocene), Souellaba (Upper Oligocene-Lower Miocene), Matanda (Upper Miocene) and Wouri Formation (Pliocene-Pleistocene).

The sedimentation of N'kapa Formation begins to the Early Paleocene and ends to the Early Eocene with a sedimentary hiatus, which separates the Eocene and Oligocene series (Salard-Cheboldaeff 1990). This formation has two members: the Bolanda Member of Paleocene to Lower Eocene age and the Dizangue Member of Eocene age (Coward et al. 1999). Two central deposits are identified: the first in the northwestern part of the basin (Bongue and Bonangando series), and the second in the southeastern part (Dizangue series). Subsurface data show that this formation is made up of continental and marine deposits. It consists essentially of mudstones, calcareous mudstones, arkosic sandstones, fine to coarse-grained sandstones, siltstones, sands and dolomites. Mfayakouo et al. (2014) and Kwetche et al. (2018) assumed N'kapa Formation to be deposited under different depositional environments, starting with fluvial continental at is lowermost part and sealed by coastal margin marine deposits in the upper part. These depositional environments include: shortface, mouth bar, shallow shelf, distal bay, fluvial floodplain and fluvial channel. This reflects a deltaic progradation from the Paleocene to an open-marine environment during the Early Eocene. This period is mainly influenced by a subsidence phase from the Paleocene to the Early Eocene (Ypresian) and uplift phase at the end of the Eocene, influencing the sea's forward and backward movements (Robertson 1992).

\section{Data and methodology}

The present study used data from fourteen hydraulic wells provided by Cameroon Water Corporation (Fig. 1). These well data consist of Gamma Ray logs, description of cuttings and the chronostratigraphic informations. The well logs go across the Paleocene-Lower Eocene interval with depths between 100 and $400 \mathrm{~m}$. To calibrate the depositional model obtained from gamma ray log patterns, the detailed outcrop information was carried out in the localities of Ngoma and Miang.

To restore depositional environments, the first step consists of characterizing the sedimentary facies (lithofacies) and their associations. The lithofacies are characterized in terms of grain size, composition, sedimentary structures and fossil content observed at the outcrops. The sedimentary facies interpretation of this study is compared to that of Postma (1990) and Miall (1996). The second step is to identify electrofacies using Gamma Ray log pattern, according to the standard model established by Emery et Myers (1996). The electrofacies model obtained was compared to the sedimentary facies or facies associations described from outcrops studied.

The sequence stratigraphy analysis from Gamma Ray $\log$ has been carried out according to Posamentier et vail (1988); Galloway (1989) and Cross et al. (1991). Thus, stacking pattern of genetic sequences on a vertical occurrences of repeated cycle of finning or coarsening upwards sequences gave rise to retrogradational, progradational, or aggradational stacking pattern. The progradational stacking pattern characterizes both the Highstand System Tract (HST) and the Lowstand System Tract (LST). The retrogradational stacking pattern represents the transgressive systems tract (TST) bounded at the base by the Sequence Boundary (SB) and at the top by the Maximum Flooding Surface (MFS). Sometimes the aggradational stacking pattern may characterize the LST and/or the HST, if the sediment supply is equal to the rate of subsidence (i.e. creation of accommodation).

In the continental domain, well logs correlations are generally difficult to establish due to frequent lateral variations in the lithofacies. Nevertheless, in this study, the reduced spacing between well logs (a few hundred metres' maximum) allows it for correlations. The Gamma Ray logs thus make it possible to distinguish the stratigraphic surfaces (Maximum Flooding Surface, Flooding Surface and Sequence Boundary). According to Van Wagoner et al.

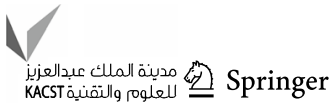


Fig. 2 Chronostratigraphic column showing formations, stratigraphic surfaces and structural events of Douala basin (from Nguene et al. 1992 and Brownfield and Charpentier 2006)

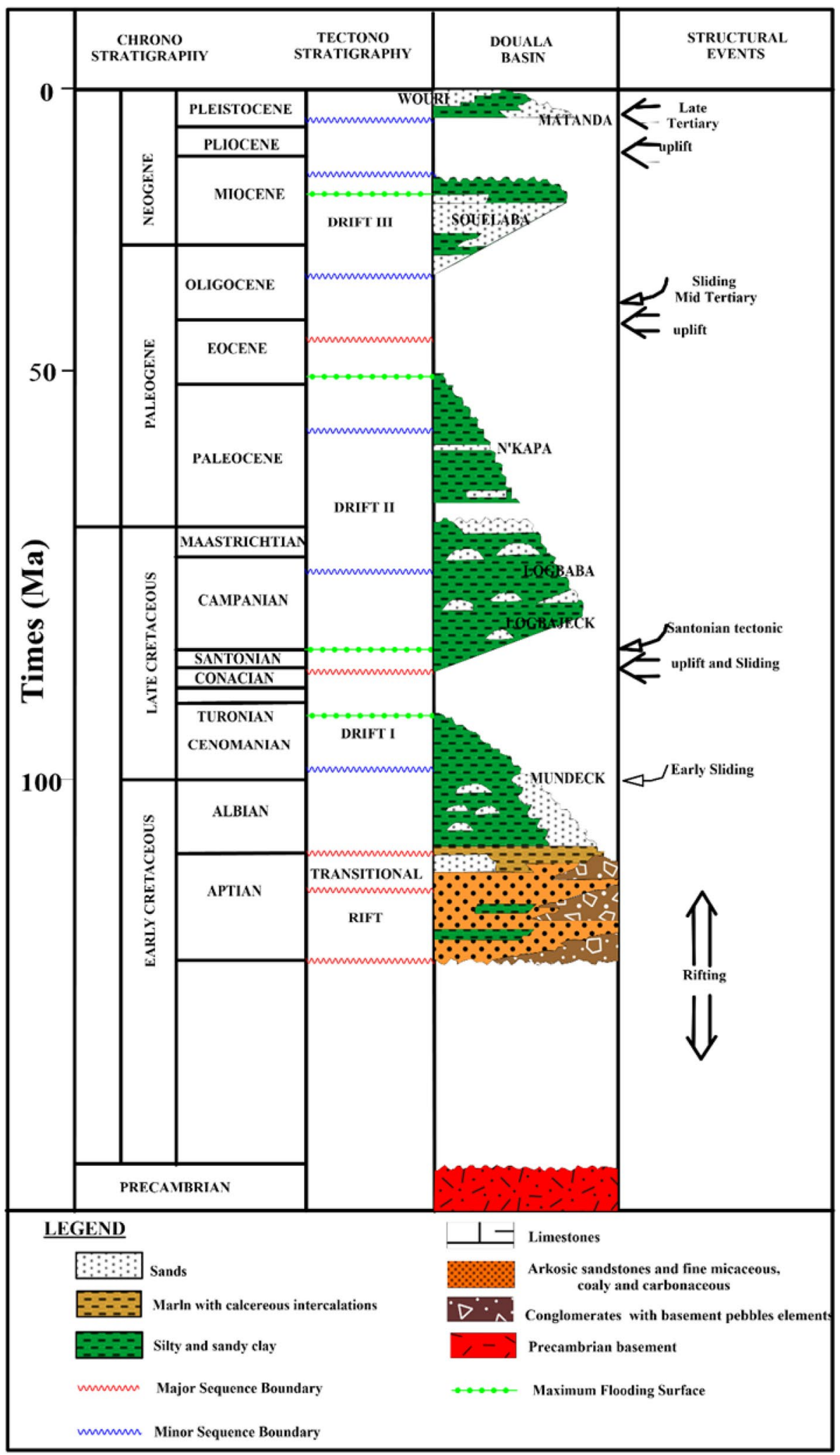

(1990); Homewood et al. (1992) and Posamentier and Allen (1999), the Maximum Flooding Surfaces (MFS) and Flooding Surfaces (FS) in a cross section are the best markers or datum. The Flooding Surfaces (FS) and Transgressive
Surface (TS) thus characterized both the base and the top of transgressive-regressive cycles (Catuneanu 2006). The duration of these cycles was derived from the biozone data published by Mbesse et al. (2012) on the reference petroleum 
well located in the north of Matanda (Fig. 1). Also, the global eustatic sea-level change whose chronology is known in the Paleogene (Haq et al. 1987 and Hardenbol et al. 1998) was used.

\section{Results and discussion}

\section{Sedimentary facies analysis}

The sedimentary facies were described from a few existing tertiary age outcrops. Ten lithofacies were identified (Fig. 3) according to grain size and composition, sedimentary structures and fossil content and interpreted in terms of depositional process as shown in Table 1. These lithofacies were further classified into three facies associations (Fig. 4): tidaldominated coastal plain (FA1), fluvial-dominated coastal plain (FA2) and fluvial floodplain (FA3).

\section{Tidal-dominated coastal plain (FA1)}

This facies association consists mainly of dark grey silty clays (FN1) and dark grey clays with a laminated aspect (FN5). The high content of organic matter indicates a calm and confined or closed environment. The presence of moulds of fossils and pyrite gives to these deposits a shallow marine character. The presence of coal and micas would indicate a terrigenous origin. According to Postma (1990), this facies association is interpreted as coastal plain deposits with tidal influence.
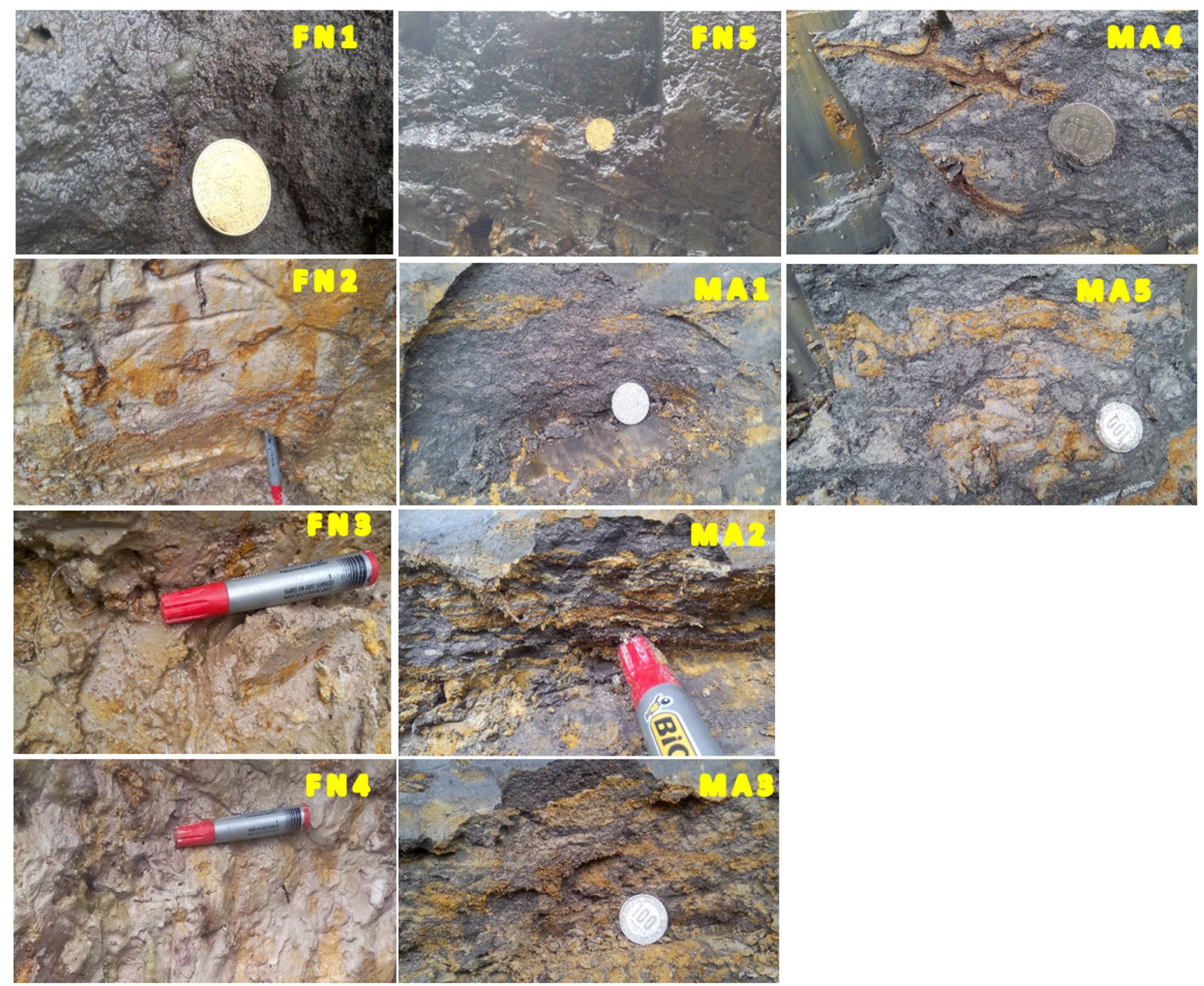

Fig. 3 Outcrop photography showing identified sedimentary facies. Silty claystones dark grey (FN1), fine to medium sandstones with mud matrix supported (FN2), Silty claystones light grey (FN3), Claystones light grey (FN4), Claystones dark grey (FN5), Claystones with lenticular and flaser siltstones (MA1), Planar laminated siltstones heterolithic (MA2), Silstones (MA3), Silty sandstones (MA4) and Fine sandstones with mud matrix supported (MA5) 


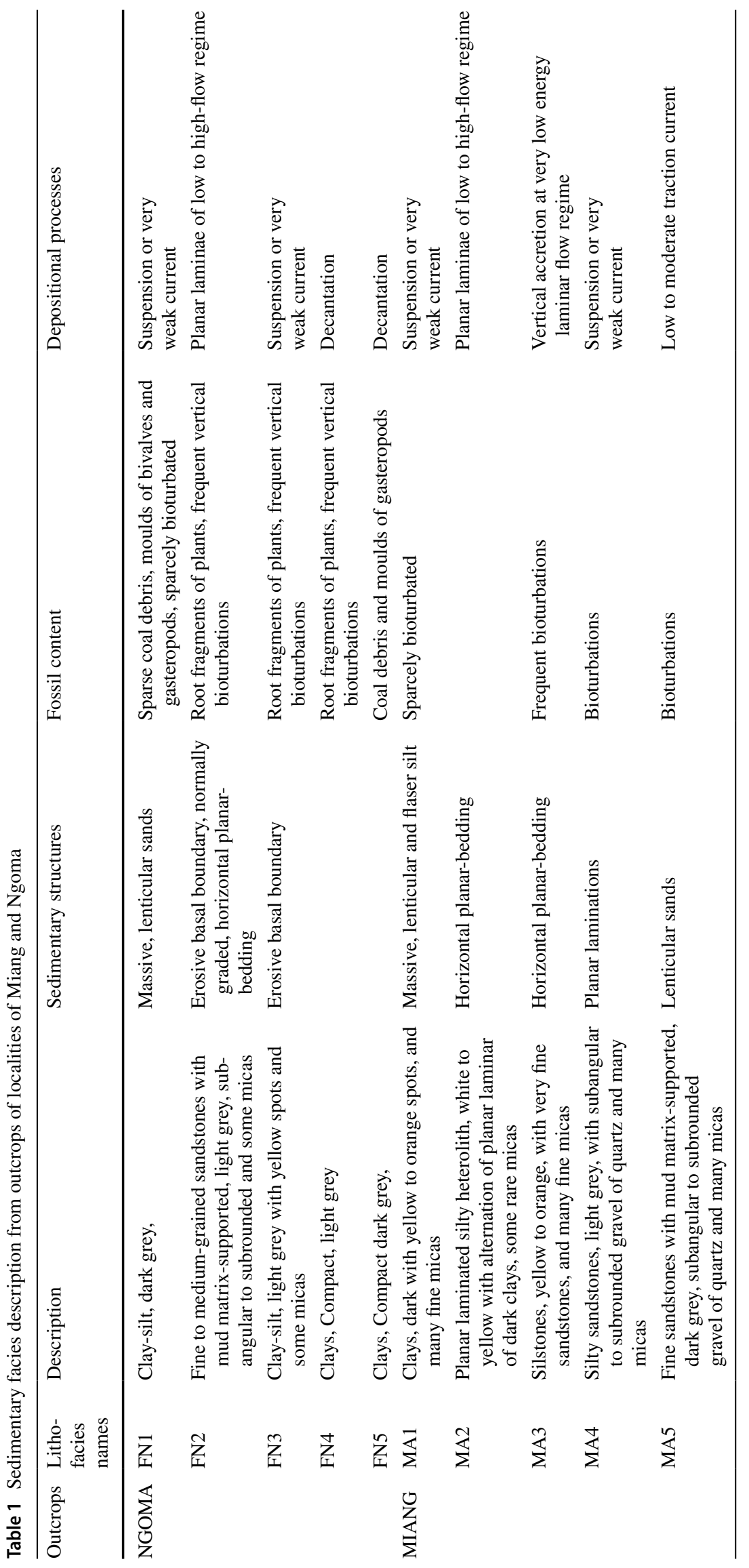


Fig. 4 Synthetic $\log$ (Well 10) including: electrofacies, lithologic description of cuttings, facies associations and depositional environments in the Eastern of Douala onshore basin

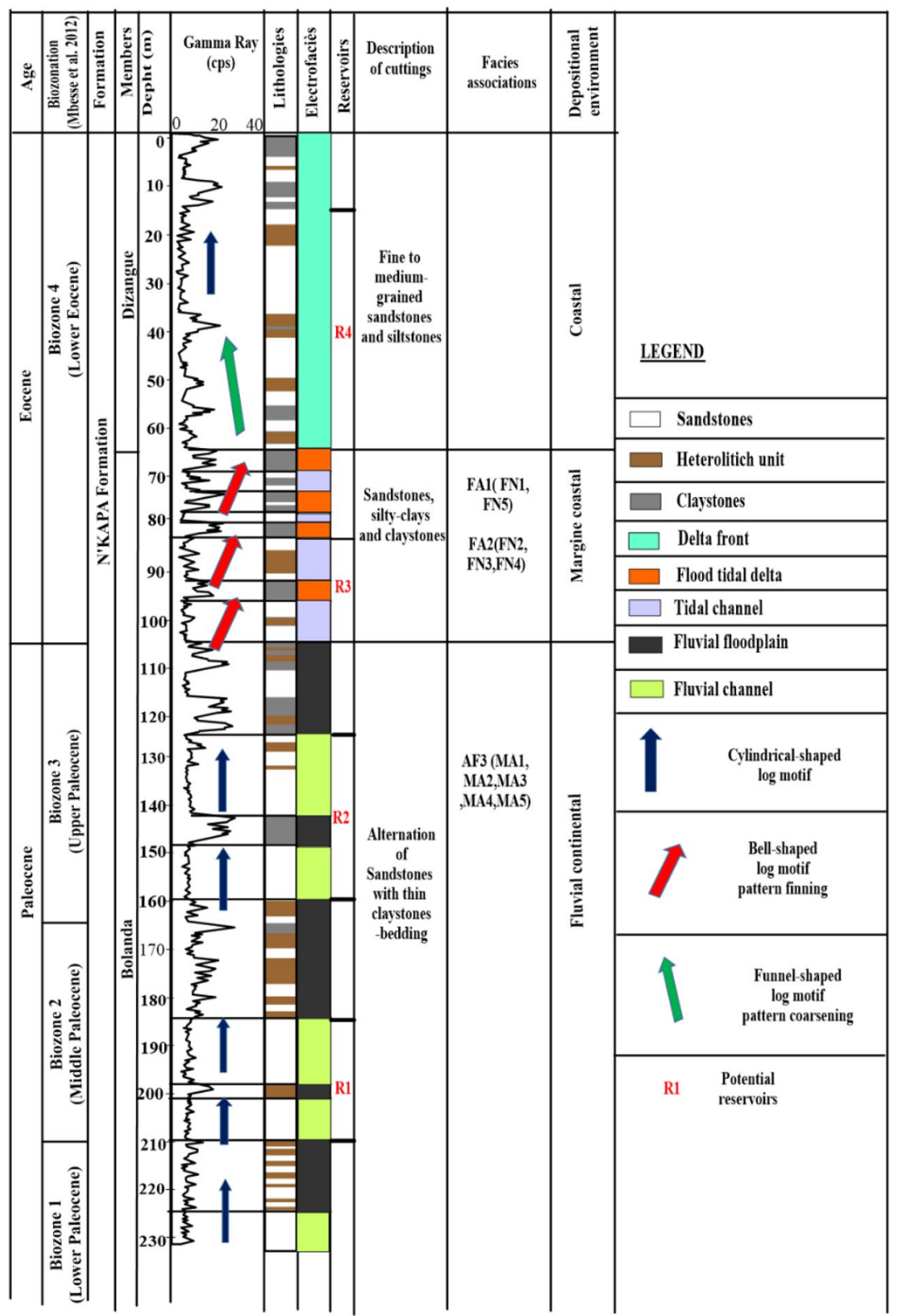

\section{Fluvial-dominated coastal plain (FA2)}

This association consists of fine to medium-grained sandstones with a mud matrix (FN2) alternating with thin planar laminated light grey clays (FN3) and light grey silty clays (FN4). The fining-upward of sandstone succession could represent a channel-fill. The clay facies reflects overbank and floodplain deposits (Miall 1996). The presence of roots (rhizolites) and micas would indicate a terrigenous sediment. Also, the presence of bioturbations in the vertical direction, horizontal planar-bedding and alternation of thin clay-bedding interstratified with deposits of very low thickness, sandstone-bedding, suggests coastal plain deposits with fluvial influence.
Fluvial floodplain (FA3)

This facies association consists essentially of planar laminated sandstone-bedding (MA4 and MA5), siltstones (MA2 and MA3) and claystones (MA1). It reflects the increasing in the grain size and the rising in the depositional energy. This facies association characterizes the distal fluvial system dominated by silt and clay deposits (Miall 1996).

\section{Electrofacies analysis}

The facies associations have been associated to several depositional environments observed in the outcrops with specific Gamma Ray log patterns (Fig. 4). Three electrofacies (EF2, 
EF3 and EF4) could be directly linked to the sedimentary facies observed on the outcrops descriptions: the fluvial floodplain, the tidal channel and the flood tidal delta. Two other electrofacies are described only based of Gamma Ray log patterns: the fluvial channel and the delta front (EF1 and EF5).

\section{Fluvial channel (EF1)}

The fluvial channels (EF1) consist of braided channels and meandering channels (Galloway and Hobbay 1983). The difference between these two types of channels does not seem obvious from the Gamma Ray log motif in this study. The fluvial channel is characterized by blocky or fining upward succession of medium to coarse-grained sandstones. The Gamma Ray log motif is cylindrical-shaped and has almost straight curves (Fig. 4). The lithology consists of fine-coarse sandstones interstratified with thin claystones-bedding.

\section{Fluvial floodplain (EF2)}

The Gamma Ray log motif is serrated-shaped due to claystones units locally separated by thin sandstones-bedding (Fig. 4). The fluvial floodplain is characterized by high Gamma Ray due to the presence of radioactive minerals in claystones (Hamon and Merzeraud 2005). The lithology consists of dark-grey silty claystones and dark-grey claystones.

\section{Tidal channel (EF3)}

The Gamma Ray log motif is bell-shaped (Fig. 4) due to frequent fluctuations in current intensity of tidal process (Dim et al. 2018). The tidal channel is characterized by fining upward of clayey sandstones bodies.

\section{Flood tidal delta (EF4)}

This electrofacies is alternated with tidal channels facies. The flood tidal delta is characterized by fairly high Gamma Ray and consists of claystones (Fig. 4).

\section{Delta front (EF5)}

The Gamma Ray log motif consists predominantly of funnelshaped (Fig. 4). It also exhibits a typical shaped coarsening upward of sandstones. The lithology is dominated by medium to fine-grained sandstones and siltstones.

\section{Depositional model}

Detailed outcrops description suggests two depositional environments. The first corresponds to a continental fluvial environment in the locality of Miang. It is characterized by fluvial floodplain facies (FA3). It consists of horizontal planar fine-grained sandstones (MA4 and MA5), siltstones (MA2 and MA3) and claystones (MA1). The coarsening upward succession reflects the increasing in the grain size and the rising in the depositional energy. It is represented by distal deposits that probably corresponds, according to Abdelkrim and Rachid (2017), to a distal fluvial system near the coastal plain. The second depositional environment in the locality of Ngoma corresponds to a coastal deltaic environment dominated by fluvial (FA2) and sometimes tidal (FA1) process. It is represented by silty claystones (FN1), fine to medium-grained sandstones (FN2) intertstratified with thin claystone-bedding (FN3) and clayey siltstones (FN4), and at the top dark grey siltsones (FN5). The fining upward succession reflects the decreasing in the grain size and the falling in the depositional energy, characteristic of a channel-fill. The cyclicity of the sandstones and silty claystones facies shows that their deposition took place in a fluvial environment with tidal processes.

The correlation between sedimentary facies description and electrofacies analysis show similarities in paleoenvironment fluctuations. According to the Gamma Ray log motif, the Paleocene-Lower Eocene interval consists of three depositional settings (Fig. 4): Fluvial continental, margined coastal and coastal. The fluvial continental environment is composed of fluvial channels (EF1) and floodplain deposits (EF2). The Gamma Ray log motif is almost straight. In the margined coastal environment, the tidal channel (EF3) and the flood tidal delta (EF4) are recognized by bell-shaped gamma ray log motif. It characterizes by the frequent fluctuations due to the tidal process (Chongwain et al. 2019) and indicates the major eustatic rise (Haq et al. 1987; Hardenbol et al. 1998) of the Paleogene (Ypresian age). The coastal environment is characterized by delta front facies (EF5). It consists of coarsening upward succession.

The Paleocene-Lower Eocene sedimentation thus corresponds to an evolution of depositional environments from fluvial continental to the shallow marine in the upper part (Fig. 5). In the Paleocene, sedimentation is essentially sandstones and dominated by fluvial dynamics in the continental environment with the development of channels and floodplains facies. In the earliest Eocene, sedimentation consists predominantly of claystones, that confirms the flattening of the depositional profile. The fluvial dynamics are attenuated and the tidal process are dominant in a delta plain setting. At the Early Eocene, fluvial process dominates over tidal process. The delta front facies formed during this period characterizes a coastal marine environment. According to Mfayakouo et al. (2014) and Kwetche et al. (2018), the sedimentation of Paleocene-Lower Eocene reflects a deltaic progradation to a deep-open marine environment. It is mainly 


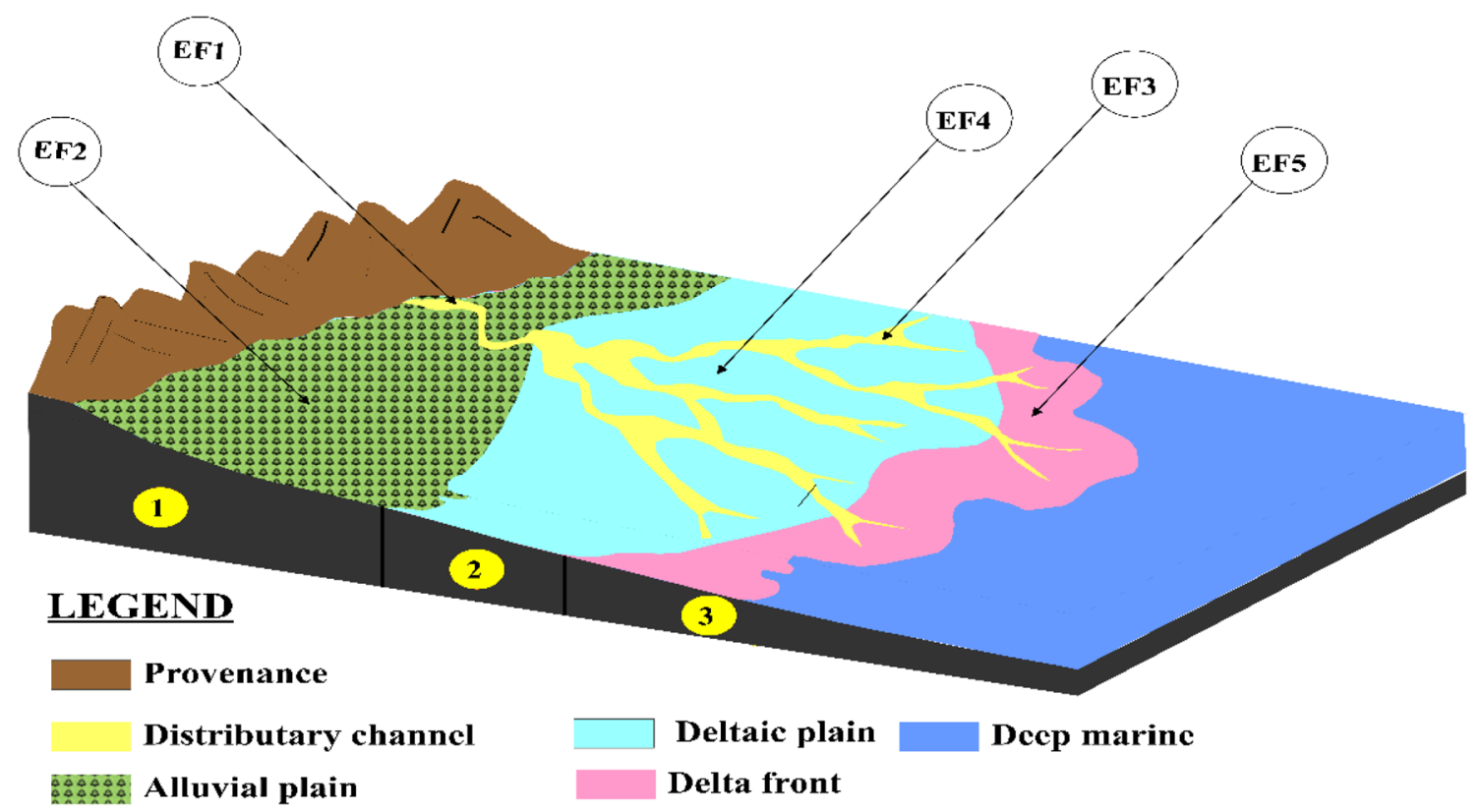

Fig. 5 Depositional model for Paleocene-Lower Eocene N'kapa Formation showing distribution of five electrofacies interpreted in this study, namely EF1-Fluvial channel, EF2-Fluvial floodplain, EF3-

influenced by a subsidence phase and uplift phase, which has an effect on the relative sea-level fluctuations (Robertson 1992).

\section{Stratigraphic architecture}

The sequence stratigraphy from Gamma Ray log was used to define the stacking pattern of the depositional systems. Two transgressive-regressive cycles (Fig. 6) comprising Lowstand Systems Tract (LST), Transgressive Systems Tract (TST) and Highstand Systems Tract (HST) packages were recognized. These cycles of 5-10 Ma are assigned to the second order (Vail et al. 1991): Lower Paleocene-Middle Paleocene (Danian-Selandian) and Upper Paleocene-Lower Eocene (Thanetian-Ypresian).

The systems tracts identified within these cycles are limited at the base and the top by four major stratigraphic surfaces: SB1, TS, MFS and SB2. According to Manga (2008) and Mvondo (2010), the SB1 is associated to the sea-level fall of the Selandian top boundary (Bolanda Member) and the SB2 to the sea-level fall of the Ypresian-Lutetian boundary (Dizangue Member). The MFS corresponds to the maximum sea-level rise of the Paleogene (Ypresian age) according to the charter of Haq et al (1987) recalibrated by Hardenbol et al (1998). The outcrop information shows that the TS is characterized by an alignment of rounded quartz pebbles (Mfayakouo et al. 2014).

Two Highstand System Tracts (HST1 and HST2), one Lowstand System Tract (LST2) and one Trangressive
Tidal channel, EF4-Flood tidal delta and EF5-Front delta. (1): Fluvial continental, (2) Margin coastal and (3) Coastal environments

System Tract (TST) are identified. The HST1 of Early Paleocene (Danian to Selandian) age is characterized by a fluvial aggradation. The base-level rise slows down and becomes less rapid than the terrigenous sediments supply. Kenfack et al. (2012) shows that the Early Paleocene is regressive and characterized by a flora dominated by continental specimens. The fluvial channels form amalgamated thin sandstones bodies (Chongwain et al. 2019). Clayey sandstones associated with pyrite indicate shallow marine deposits influenced by a significant fluvial process. This period ends with an erosive boundary on which incised valleys are formed. The fluvial channel-fill tends to connect and forms amalgamated sandstones bodies with reservoir potentials according to Selley (2000). The LST2 of Late Paleocene (Early Thanetian) age is located on the top boundary of HST1. The base-level rise more slowly than the rate of sedimentation. This period is characterized by a small episode of fluvial aggradation and the development of incised valleys (Galloway and Hobday 1983). The hydrogeological interest lies on the incised valley fill sandstones developed above the erosional boundary SB1. The TST2 of Late Paleocene to Early Eocene (Late Thanetian to Early Ypresian) age consists of coastal marine deposits due to the base-level that rises faster than the terrigenous sediments supply. The coastal environment is subject to erosion from waves and storms that produce a ravinement surface (TS?). During this period, sedimentation takes place in rivers and mouths (estuaries). This episode is characterized by tidal channel-fill or accretion deposits set up during the aggradation phase. These channels consist of

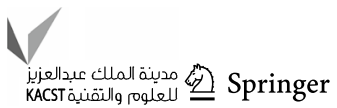




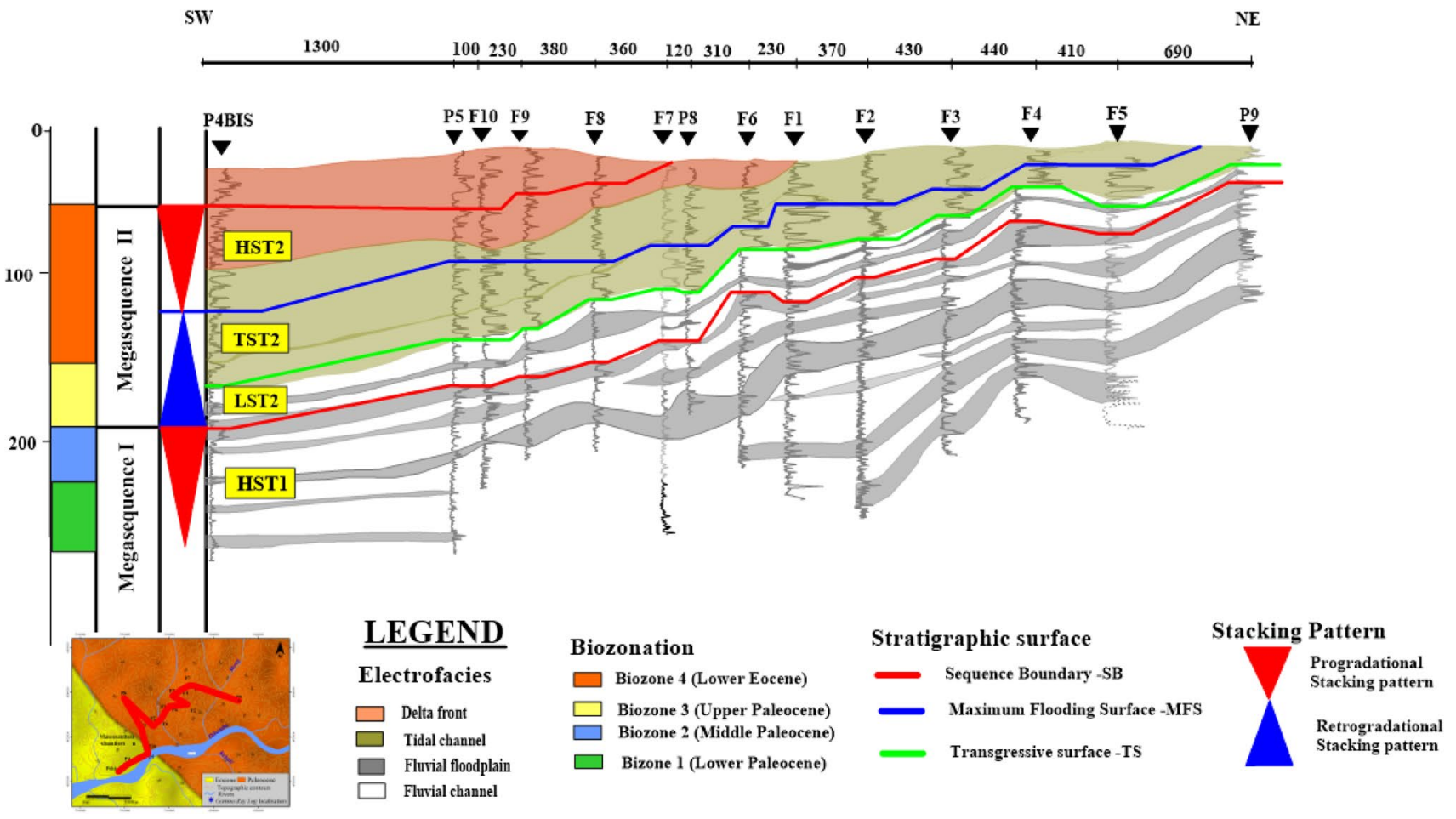

Fig. 6 Well logs cross section including four chronostratigraphic surfaces (SB1, TS, MFS and SB2, respectively), four systems tracts (HST1, LST2, TST2 and HST2, respectively) two depositional

thin sinuous sandy bodies of limited extension which are sometimes very clayey. In this depositional sequence, it is rather a question of looking for source rocks than reservoirs, especially in claystones which are rich in organic matter. Finally, the HST2 of Early Eocene (Late Ypresian) age is formed during the second period of base-level rise. During this phase, the amalgamated channels form coastal sandstones bodies with reservoir capacities (Galloway and Hobday 1983). These sands bodies have a very large extension which is linked to the continuity in time of the longitudinal currents.

\section{Clay volume $\left(\% \mathrm{~V}_{\text {sh }}\right)$ and nature of potential reservoirs}

Gamma ray log analysis from selected wells (F10, F7 and F3) has enabled the identification of potential reservoirs which correspond to intervals of low gamma ray values and whose amplitude is greater than or equal to $10 \mathrm{~m}$. Also, depending on the argillaceous nature of these intervals, the identified potential reservoirs have been specified. Thus, the identified interval is considered sandstone for clay volume $\left(\mathrm{V}_{\mathrm{sh}}\right)$ values between 0 and $15 \%$; clayey sandstone for those ranging from 15 to $30 \%$ and sandstone highly clayey (clay content ranging from 30 and 45\%). After examination (Table 2 and Fig. 4) based on the gamma ray well log sequences (Magasequence I et Megasequence 2) and electrofacies of Paleocene-Lower Eocene aquifer systems the Eastern of Douala onshore basin

correlation, a number variable from three to four potential reservoirs has been identified in N'kappa Formation. The volume of clays (7.6-21.45\%) shows that the clay content increases in these reservoirs from NE to SW (Fig. 6). The reservoirs are of variable thickness (9-32 $\mathrm{m}$ ) and consist of two lithological facies: clean sandstone and low clayey sandstone.

The Paleocene-Lower Eocene N'kapa Formation not constitute good hydrogeological reservoirs. The majority of sedimentary bodies were deposited during the highstand (Fig. 7) from the Early Paleocene (Danian-Selandian) and Early Eocene (Late Ypresian). Moreover, the water exploitation works of this formation by companies show that the potential aquifer consists of clayey sandstones and hence their rather poor permeability characteristics. The coarser and cleaner sands, with potentially better reservoir quality, are generally restricted to the basin margins, where they are found near the surface. This study shows that these aquifers of the eastern part of the basin will be very poorly sealed due to uplift and erosion of the basin margins. Most of the channel sandstone bodies aquifers are sinuous and sometimes very clayey. It is also very thin, isolated from each other and heterogeneous. According to Catuneanu (2006), the channelfill sandstones deposited during the Lowstand System Tract (LST2) constitute good reservoirs; therefore, only the aquifers established in the earliest Thanetian can be exploited as 
Table 2 Clay volume $\left(\% V_{\text {sh }}\right)$ and nature of potential reservoirs at wells F10, F7 and F3

\begin{tabular}{lllll}
\hline Well name & $\begin{array}{l}\text { Potential reser- } \\
\text { voirs }\end{array}$ & Thickness $(\mathrm{m})$ & $\begin{array}{l}\text { Volume of clay } \\
\left(\% V_{\text {sh }}\right)\end{array}$ & Lithology \\
\hline F10 & R1 & 23 & 17 & Low clayey sandstone \\
& R2 & 12 & 12.3 & Clean sandstone \\
& R3 & 11.5 & 15.05 & Clean sandstone \\
& R4 & 26.5 & 21.45 & Low clayey sandstone \\
F7 & R1 & 21 & 13.8 & Clean sandstone \\
& R2 & 12 & 12.6 & Clean sandstone \\
& R3 & 10.5 & 19.95 & Low clayey sandstone \\
& R4 & 12 & 17.1 & Low clayey sandstone \\
F3 & R1 & 12 & 7.6 & Clean sandstone \\
& R2 & 27 & 9.2 & Clean sandstone \\
& R3 & 13.5 & 8.85 & Clean sandstone \\
\hline
\end{tabular}

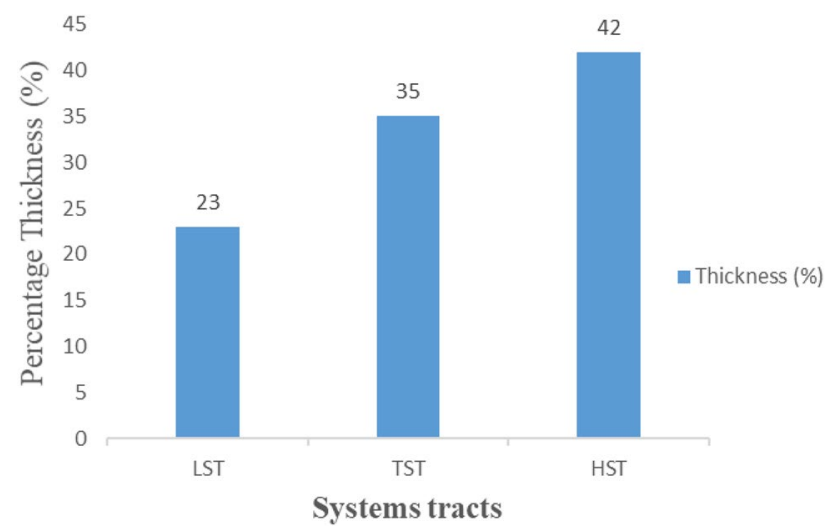

Fig. 7 Average percentage thickness distribution of systems tracts across the Eastern Douala onshore basin showing predominance of highstand system tract (HST) packages during Paleocene-Lower Eocene interval

potential aquifers. Because of their very low radioactivity (clean sandstones), they constitute excellent reservoirs which underly the claystone cover. The other argument in favour of this hypothesis is its depth and comprises between 100 and $200 \mathrm{~m}$ which isolates it from surface pollution. TST2 deposits would be a target for the search for source rocks. Moreover, the work of Kenfack et al (2012) shows that its oil potential is poor to fairly good.

\section{Conclusion}

The results obtained from this study provide new data on the spatio-temporal evolution of sedimentary systems during the Paleocene-Early Eocene. Sedimentation in the N'kapa Formation is characterized by a fluvial continental to shallow marine deposits. Sequence stratigraphy analysis reveals two transgressive-regressive cycles of second order (Danian to Selandian and Thanetian to Ypresian), two Highstand
System Tracts (HST1 and HST2), one Transgressive System Tract (TST2) and one Lowstand System Tract (LST2). Based on these observations, the sand/sandstone bodies that make up potential aquifers depend on lithofacies and depositional environments. The sedimentary bodies which are potential aquifers are associated with fluvial channel-fill sands, tidal channel-fill sands and delta front bars sands. Their distribution in time and space appears to be related to the hydrodynamics and topography of the depositional environments. A total of two types of lithological facies of the reservoir levels were defined according to the volume of clay: clean sandstone (0-15\%) and low clayey sandstone (15-30\%). The gamma ray well log correlation shows that the thickness of the reservoir levels is variable and that the clay content $\left(\mathrm{V}_{\mathrm{sh}} \%\right)$ increases from the NE to the SW. To make a complete evaluation of the petrophysical parameters (porosity, permeability and fluid saturation) of the different reservoir levels, it is recommended to associate the GR logs with other logs such as resistivity, density, neutron and sonic.

Acknowledgements The authors would like to gratitude to the Cameroon Water Corporation (CAMWATER) for giving us access to the well data used in this study, through the convention with the University of Yaounde 1. Special thanks to Michel LOPEZ (University of Montpellier 2) for his collaboration in the methodology part of this work.

Funding The authors have declared no funding.

Open Access This article is licensed under a Creative Commons Attribution 4.0 International License, which permits use, sharing, adaptation, distribution and reproduction in any medium or format, as long as you give appropriate credit to the original author(s) and the source, provide a link to the Creative Commons licence, and indicate if changes were made. The images or other third party material in this article are included in the article's Creative Commons licence, unless indicated otherwise in a credit line to the material. If material is not included in the article's Creative Commons licence and your intended use is not permitted by statutory regulation or exceeds the permitted use, you will need to obtain permission directly from the copyright holder. To view a copy of this licence, visit http://creativecommons.org/licenses/by/4.0/. 


\section{References}

Abdelkrim A, Rachid E (2017) Sédimentologie de faciès des dépôts triassiques de la region d'Oued El Maleh et Elgara (bassin de MohamedBenslimane-Elgara-Berrechid Maroc. Int J Adv Res 5:1938-1949

Bourquin S, Boehm C, Clermonté J, Durand M, Serra O (1993) Analyse facio-séquentielle du Trias du Centre-Ouest du bassin de Paris à partir des données diagraphiques. Bulletin de la société Géologique de France 164:177-188

Brownfield ME, Charpentier RR (2006) Geology and total petroleum systems of the West-Central Coastal Province (7203). United States Geological Survey, West Africa, p 52

Catuneanu O (2006) Principles of Sequence Stratigraphy, 1st edn. Elsevier, Amsterdam, p 375

Chongwain GC, Osinowo OO, Ntamak Nida MJ, Nkwanyang TL (2019) Lithological typing, depositional environments, and reservoir quality characterization of the 'M-Field' Douala basin, Cameroon. J Pet Explor Prod Technol 9:1705-1721. https://doi. org/10.1007/s13202-019-0648

Coward MP, Purdy EG, Ries AC, Smith DG (1999) The distribution of petroleum reserves in basins of the South Atlantic margins. Geol Soc London Special Publ 153:101-131

Cross TA (1991) High-resolution stratigraphic correlation from the perspectives of base-level cycles and sediment accommodation. In: Dolson J (ed) Unconformity related hydrocarbon exploration and accumulation in clastic and carbonate settings, short course notes. Rocky Mountain Association of geologists, Denver, pp 28-41

Dim CIP, Onuoha KM, Mode AW, Okwara IC, Okeugo CG (2018) Characterizing the middle-upper miocene reservoir intervals of a producing field in the Niger Delta basin: an application of facies, sequence stratigraphic and petrophysical analyses. Arabian J Sci Eng 44:429-448

Emery D, Myers KJ (1996) Sequence stratigraphy. Blackwell Sciences Ltd, Oxford, p 297p

Galloway WE (1989) Genetic stratigraphic sequences in basin analysis. I. Architecture and genesis of flooding-surface bounded depositional units. Am Asso Petrol Geol Bull 73:125-142

Galloway WE, Hobday DK (1983) Terrigenous clastic depositional systems. Springer-Verlag, New York, $p$ 423p

Hamon Y, Merzeraud G (2005) Nouvelles données sur le Trias de Sologne (Chémery, sud-ouest du bassin de Paris): stratigraphie et environnements de dépôts. Bulletin de la Société. Géologique de France 1:3-22

Haq BU, Hardenbol J, Vail PR (1987) Chronology of fluctuating sea levels since the triassic. Sciences 235:1156-1167

Hardenbol J, Thierry J, Farley MB, Jacquin T, Graciansky PC, Vail PR (1998) Mesozoic and Cenozoic Sequence Chronostratigraphic Framework of European Basins. SEPM Special Publication, 60: p 786

Homewood P, Guillocheau F, Eschard R, Cross TA (1992) Corrélations haute résolution et stratigraphie génétique: une démarche intégrée. Bull Cent Recherche Explor-Prod Elf-Aquitaine 16(2):357-381

Kenfack PL, Njike Ngaha PR, Ekodeck GE, Ngueutchoua G (2012) Fossils dinoflagellates from the northern border of the Douala sedimentary sub-basin (South-West Cameroon): age assessment and paleoecological interpretations. Geosciences 2:117-124

Kwetche FP, Ntamak Nida M, Nitcheu A, Etame J, Mvondo F, Mbesse C, Kissaaka J, Ngon Ngon G, Bourquin S, Bilong P (2018) Facies analysis and sequence stratigraphy of missole outcrops: N'Kapa Formation of the South-Eastern edge of douala sub-basin (Cameroon). Earth Sci Res Canadian Center Sci Educ 7:35-54

Lawrence SR, Munday S, Bray R (2002) Regional geology and geophysics of the eastern Gulf of Guinea (Niger Delta to Rio Muni). Lead Edge 21(11):1065-1176. https://doi.org/10.1190/1.1523752

Manga CS (2008) Stratigraphy, structure and prospectivity of the Southern onshore Douala Basin, Cameroon Central Africa. Africa Geosci Rev 1:13-37
Mbesse CO, Roche E, Ngos S III (2012) The Paleocene-Eocene boundary in the Douala Basin (Cameroon): Dinocysts biostratigraphy and tentative of Paleoenvironmental reconstruction. Int $\mathbf{J}$ Trop Geol Geogr 36:83-119

Meyers JB, Rosendahl BR, Groschel-Becker H, Austin JJA, Rona PA (1996) Deep penetrating MCS imaging of the rift-to drift transition, offshore Douala and North Gabon basins, West Africa. Mar Pet Geol 13:791-835. https://doi.org/10.1016/02648172(96)00030-X

Mfayakouo BC, Njike Ngaha PR, Bitom DL (2014) Sedimentary facies and depositional environments of Cenozoïc sedimentary Formations cropping out at the central part of the Douala basin. Am J Geosci 4(1):8-23. https://doi.org/10.3844/ajgs.2014.8.23

Miall AD (1996) The geology of fluvial deposits: sedimentary facies, basin analysis and petroleum geology, 1st edn. Springer-Verlag, Berlin, p 582p

Mohammad AS (2015) High resolution sequence stratigraphic analysis of the Late Miocene Abu Madi Formation Nothern Nile Delta Basin. NRIAG J Astron Geophys 4(2):298-306. https://doi. org/10.1016/j.nrjag.2015.11.003

Mvondo (2010) Cenozoic uplift of West Africa from two examples: the Southern Namibian plateau and the northern margin of Cameroon. Doctoral thesis, University of Renne. p 324

Nguene FR, Tamfu, SF, Loule, JP, Ngassa, C, (1992) Paleoenvironments of the Douala and Kribi/Campo subbasins, in Cameroon, West Africa. In: Curnelle R (Ed.) Géologie Africaine. 1er Colloque de Stratigraphie et de Paléogéographie des Bassins Sédimentaires Ouest-Africains. 2ème Colloque Africain de Micropaléontologie, 6-8 Mai 1991, Libreville, Gabon. Bulletin du Centres de Recherche. Exploration-Production, Elf Aquitaine, 13, 129-139

Pauken RJ, Thompson JM, Schuman JR, Cooke JC (1991) Geology of the Douala Basin, offshore Cameroon. Am Assoc Pet Gelogists Bull United States 75:651-652

Posamentier HW, Allen GP (1999) Siliciclastic sequences stratigraphyconcepts and application. SEPM (Society for Sedimentary Geology), Oklahoma, p 210p

Posamentier HW, Jervey MT, Vail PR (1988) Eustatics control on clastic deposition I-Conceptual framework. S.P.E.M. Special Pub. Tulsa 42:109-124

Postma G (1990) Depositional Architecture and Facies of River and Fan Deltas: A Synthesis. In: Colella A, Prior DB (eds) Coarsegrained Deltas Special Publications of International Association of Sedimentologist. Wiley, Oxford, Boston, p 368p

Rider MH (1991) The geological interpretation of well logs. Revised eddition. Whittles Publishing, Dunbeath, p 175p

Robertson S (1992) The biostratigraphy and palaeoenvironnement of seven wells from the Douala Basin, Cameroon. Recherche Explor Prod Elf-Aquitaine 14:213-384

Salard-Cheboldaeff M (1990) Intertropical African palynostratigraphy from Cretaceous to Late Quaternary times. J Afr Earth Sc 11:1-24

Selley RC (2000) Applied Sedimentology, 2nd edn. Royal school of mines, Imperial College London. Academic press, San Diego, pp 56-82

Serra O (1986) Differed well log: their use in Sedimentary geology. Bull Cent rech Expl-Prod Elf Aquitaine 10:205-227

Vail PR, Audemard F, Bowman SA, Eisner PN, Perez-Cruz C (1991) The stratigraphic signatures of tectonics, eustasy and sedimentology-an overview. In: Einsel G, Ricken W, Seilacher A (eds) Cycles and events in stratigraphy. Springer, Berlin, pp 617-659

Van Wagoner JC, Mitchurn RM, Campion KM, Rahmanian VD (1990) Siliciclastic sequence stratigraphy in well logs, cores and outcrops. MPG Methods in Explor Series 7:55p

Publisher's Note Springer Nature remains neutral with regard to jurisdictional claims in published maps and institutional affiliations. 